\title{
Transparency Regarding the Tax Avoidance in Indonesia: A Philosophical Review
}

\author{
Yudi Yasmin Wijaya \\ University of Jember, Indonesia \\ yudiyw123@gmail.com
}

\author{
A'an Efendi \\ University of Jember, Indonesia \\ aan_efendi.fh@unej.ac.id \\ Fanny Tanuwijaya \\ University of Jember, Indonesia \\ fanny.tanuwijaya@unej.ac.id \\ Nilna Aliyan Hamida \\ University of Jember, Indonesia \\ nilnahamida@gmail.com
}

\begin{abstract}
Tax avoidance has become a significant problem that adversely impacts the state's financial system, and its impact can obstruct the state, resulting in distrust of the government. The distrust towards the government, generally due to the reason for tax avoidance. Tax avoidance is fundamentally people's awareness of economic democracy. In Indonesia, the current discussion refers to the Tax Procedure Act, specifically regulates the obligation of the taxpayer, but limiting the rights of taxpayers. It becomes a crucial problem of transparency as part of social rights. Although the activities indicate democratic practice but other critical challenges affect its implementation. The state, as a people's forum, has an unrealized purpose and has the potential national disintegration. The potential of disintegration forms transparency in the taxation system. Transparency in the tax management can provide accountability between the government and citizens to maintain the effectiveness of tax administration. Using transparency in the taxation system is an excellent solution for a democratic economy. By using doctrinal research, tax transparency has aspects of being balanced to realize the welfare of the country. Balancing the features of the taxation system requires the right transmission to achieve the country's purpose for people's welfare.
\end{abstract}

KEYWORDS: Transparency, Tax Avoidance, Tax Law.

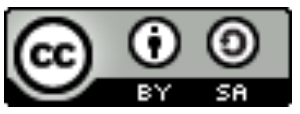

Copyright $\odot 2020$ by Author(s)

This work is licensed under a Creative Commons Attribution-ShareAlike 4.0 International License. All writings published in this journal are personal views of the authors and do not represent the views of this journal and the author's affiliated institutions. 


\section{HOW TO CITE:}

Wijaya, Yudi Yasmin et al. "Transparency Regarding the Tax Avoidance in Indonesia: A Philosophical Review” (2020) 7:1 Lentera Hukum 85-100.

Submitted: July 06, 2019 Revised: February 15, 2020 Accepted: February 27, 2020

\section{INTRODUCTION}

The topic of tax is related to economic factors. One crucial element is the taxation system. ${ }^{1}$ However, executing the taxation system needs humanitarian factors related to economic problems. The challenges in this situation originated from the boundless human desire. ${ }^{2}$ Based on desire, people make restrictions to control their rights and obligations. The rights are expressed in obligations that should implement and actualize through group formation. The group aims to fulfill certain objectives. One form of group is the state. ${ }^{3}$ In order to do the duties, the state creates a set of rules intended for stability. The purpose of the rules is to provide public protection and guarantees the owner of the right to execute their obligations. ${ }^{4}$ In order to realize the prosperity of the people, the state executes various development efforts, such as improving the quality of infrastructure, education, law, state security, and others. ${ }^{5}$ Implementation of development requires financial support, which arises from state taxes. The method of financing is determined based on a tax collection system for citizens. ${ }^{6}$ The tax used to realize the state's purpose, such as the prosperity of the people. The aim of realizing prosperity is a fundamental aspect to establish the state as a practice of democracy. ${ }^{7}$

The concept of democracy from taxation is the discourse to emphasizes the democratization of tax management. ${ }^{8}$ However, the people as the representative in the government still practiced the closed process of tax management. This condition leads the excellent management to become blurred, so it implicates people hesitancy to pay

1 Mireille Laroche, Marcel Merette \& GC Ruggeri, "On the Concept and Dimensions of Human Capital in a Knowledge-Based Economy Context" (1999) XXV:I Can Public Policy 90.

2 The matters were based on the growth of the numbers of human that keeps on the increase. See Edward J O'Boyle, "On Need, Wants, Resources and Limits" (1993) 20:12 Int J Socia Econ 13-26. at 21.

3 Alberto Alesina \& Reich Bryony, "Nation building” (2013) wl8839 Natl Bur Econ Res.at 3.

4 Those set of rules was adjusted with the purpose of the state to ensure justice on interest, purpose, and choices of the public. See Ibid.

5 See Noel D Johnson, "Taxes, National Identity, and Nation Building: Evidence from France" (2015) George Mason Univ Dep Econ Pap 1. at l.

6 Timothy Besley \& Torsten Persson, "Taxation and Development" in Raj Chetty, ed, Handb Public Econ Vol 5, lst ed (North Holland, 2013) 51.

7 The existence of a democratic governmental system in Indonesia caused by the will become the government of Indonesia to respect the existence of basics fundamental rights of its citizens. See Zezen Zaenal Mutaqin, "The Strong State And Pancasila: Reflecting Human Rights in the Indonesian Democracy" (2016) 2:2 Const Rev 160-188. at. 160.

8 People-based tax management is used to restrain the tyranny from the authorities. See Benno Torgler, "Tax morale and direct democracy" (2005) 21:2 Eur J Polit Econ 526. 
and find ways to avoid taxation. ${ }^{9}$ The avoidance is shown from the gap of the taxation regulations that created the terminology of tax avoidance. ${ }^{10}$ Also, this phenomenon reduces state revenue and fades the true nature of the state. The term state, as a manifestation of the state's purpose, becomes less relevant." Based on the problems, various countries in the world affirm the tax payment regulations using the rule of law. ${ }^{12}$ Although many countries have strengthened regulations regarding tax collection, tax avoidance activities have not ignored. Indonesia is a country that has experienced this condition, as a developing country with a democratic system; it will have an effect on public trust that indicates suspicion of the country. ${ }^{13}$ This situation due to the lack of explanation and appropriate application in tax regulations regarding people's rights as taxpayers, such as understanding the management of the tax revenue by the government transparently. ${ }^{14}$ There are many attempts from the government to solve this predicament, such as the statement as the slogan of tax payment obligation. However, this provision shows insignificant effects because of the regulations and implementations of a transparency system, not in line with the prospect.

This article examines the philosophical aspects of law and a set of legal regulations. Moreover, this article discussed the law enforcement situation of tax transparency. The purpose of this article is to minimize tax avoidance in Indonesia and to find solutions for a suitable set of tax regulations. The law is implementing tax transparency as a method to reduce tax avoidance. Legal studies examine the philosophical ground and the rule of law in Indonesia using doctrinal research. Doctrinal research examines the legislation products that lead the arguments from legal doctrines. ${ }^{15}$ The research was conducted based on literature studies ${ }^{16}$ with the analysis of primary and secondary sources of law without any numerical based data. ${ }^{17}$ The object of the research is the primary resources consisted of the authority, and the secondary source consists of the literature of legal and economic scholars. ${ }^{18}$

9 The people's doubt caused by the potency of abuse of power inside closed taxations managements. See Lasnofa Fasmi \& Fauzan Misra, "Modernisasi Sistem Administrasi Perpajakan dan Tingkat Kepatuhan Pengusaha Kena Pajak" (2014) 5:1 J Akunt Multiparadigma JAMAL 1-169.at 84.

10 Ioana Alexandra Horodnic, "Tax morale and institutional theory: a systematic review" (2018) 38:9/10 Int J Sociol Soc Policy 868-886. at 869.

Il The contradiction happens between the disrupted common cause from distrust factors from the people as taxpayers and government as tax collectors. See Alesina \& Bryony, supra note 3.

12 Reza Jamei, "Tax Avoidance and Corporate Governance Mechanisms: Evidence from Tehran Stock Exchange" (2017) 7:4 Int J Econ Financ Issues 638-644. at 639.

13 This statement also indicates the low morality of taxations programs. See Horodnic, supra note 10.

14 See Lynne Oats \& Penelope Tuck, “Corporate tax avoidance: is tax transparency the solution?” (2019) 49:5 Account Bus Res. at 569.

15 The doctrinal research was held by collecting the doctrines of law from various legal resources. See Terry Hutchinson, "Doctrinal research: researching the jury" in Dawn Watkins \& Mandy Burton, eds, Res Methods Law (Oxford: Routledge, 2013) 8.

16 By selecting several research aspects that have explained before. See Dyah Ochtorina Susanti \& A'an Efendi, Penelitian Hukum (Legal Research). (Jakarta: Sinar Grafika, 2018) at 11.

17 Ibid.

$18 \quad$ Ibid at 52. 
This article has two main questions. First, it inquires about the conditions of the legal basis that regulate tax transparency. This topic will discuss how the philosophical ground of the constitution and the rule of law have controlled the transparency requirements to solve the problem of tax avoidance in Indonesia. Second, it inquires about the implementation of appropriate legal policies to realize transparency in the taxation system. This topic aims to resolve and reduce the intensity of tax avoidance activities in Indonesia through a form of legal-based transparency.

\section{TRANSPARENCY IN ADDRESSING THE TAX AVOIDANCE}

\section{A. An Overview of Tax Avoidance}

The taxation process applied as the purpose of the state's development efforts. Taxes are the results of the obligatory of a person or group conducted by the state through taxation. ${ }^{19}$ The implementation of taxation is an essential activity for countries in the world..$^{20}$ This statement is based on the characteristics of tax payment as a tool of the government to increase revenue. The revenue from taxation is an additional resource for the state budget to support the development in other fields. ${ }^{21}$ The importance of the taxations for the development must be supported with specific regulation and effective management of the political and legal aspects of the state. ${ }^{22}$ In Indonesia, both aspects outlined in the state constitution as specific regulations regarding procedures for managing state taxes. In the 1945 Constitution, aspects of taxation are written in article 23 paragraph 1, and the procedure for its implementation is regulated in Act. ${ }^{23}$ The legal definition of tax contained in Law No.28 of 2007. This regulation is the third amendment of Law No.6 of 1983 concerning General Provisions and Tax Procedures. It explains the taxes are mandatory contributions from individuals or legal entities forced based on the law by indirect compensation to the state for people's prosperity. ${ }^{24}$

The welfare of citizens as the purpose of the taxation system shows the fundamental aspect of Indonesia. In his book, Soehino explained a state is a form of the human group created from a common purpose as a form of organizational authority

19 Charles E. McLure, Maria S. Cox, Fritz Neumark, Taxation. (Encyclopædia Britannica, 2018) 〈https://www.britannica.com/topic/taxation〉.

20 The importance of tax for a country was based on its traits that have a severe impact on sustainable economic development, especially for a country that still in developing states. See Lumnije Thaçi \& Arbnora Gërxhaliu, "Tax Structure and Developing Countries" (2018) 4:1 Eur J Econ Bus Stud 213220.

21 The other purpose indicated as a form of tax policy in distribution, retribution, and securing the economic benefits. Besides, the taxations as an activity are beneficial to prevent the diversions of economic conditions and also promoting economic growth. See Ibid.

22 Political and legal aspect in a good government is based on the importance of efficiency, accountability, and open governmental system that focused on the rule of law. See Reforming tax systems in the developing world: What can we learn from the past?, by Roel Dom \& Mark Miller (London, 2018).at 20.

23 Paragraph 1 Article 23 of 1945 Constitution explained about the essential traits of financial management, whereas its government regulation is applied to the first act of general requirement and taxations management or the so-called Act Number 6 of 1983.

24 Act Number 28, 2007 about Third Amendment of Act Number 6, 1983 about General Requirement and Taxation Procedure Act, Article 1, Paragraph 1. 
with the purpose of prosperity. ${ }^{25}$ This viewpoint represents the state that has a role for the people to achieve their purpose. ${ }^{26}$ This notion is supported by the statement a state exists because of the common purpose of the people and tends to escort people who have the same desires, purpose, and choices to form a completely integrated society. ${ }^{27}$ This statement shows that the practice of the taxation system must focus on the goals of citizens. Society-oriented taxation is vital for the sustainability of national development. ${ }^{28}$ The state as a tool to create a democratic taxation system in line with the statement about the group bond theory coined by I Dewa Gede Atmaja, who explains a state binds the people towards a choice that has been decided together. ${ }^{29}$

Through the mandate of the constitution, the taxes used for the welfare of people. People are the subject to oversee the utilization of the taxes as the practice of transparency in the taxation system. According to Hildreth, tax transparency refers to the symmetry of information between tax authorities and taxpayers. ${ }^{30}$ Furthermore, the meaning of tax transparency the same as information between the tax authorities and taxpayers. Taxpayers must report detailed information on their wealth and pay taxes, and vice versa while the tax authority must explain the utilization of tax and contribution from taxation. This transparency based on give guarantees to the people involved. $^{31}$ The existence of potential tax leakage generates more substantial innovations to drive the steps towards the practice of transparency. ${ }^{32}$ The utilization of obligations into the manifestation of the service will actualize the welfare of citizens in the taxation system.

Tax transparency is a form of state fiscal policy to extend economic factors. Transparency in an economic context is a critical indicator of the government's commitment to open the government's internal decision-making process. ${ }^{33}$ The transparency of the taxation is state fiscal policy to requires a commitment from the government to open the internal affairs of tax policy decision making; taxpayers will know and can make the right decision, especially regarding the decision to pay taxes. As a legal entity, the corporation is required transparency regulation because of the

25 Soehino, Ilmu Negara (Yogyakarta: Liberty, 2015) at 142.

26 The term container, in this case, is a form of media to realize the prosperity that is the purpose of the creations of the state. Ibid at 146.

27 The combination that created would lead the people towards welfare. See Alesina \& Bryony, supra note 3 .

28 Michael Wasylenko et al, "Taxation and economic development: The state of the economic literature" (1997) 2:1 N Engl Econ Rev 37.

29 M. Iwan Satriawan \& Siti Khoiriah, Ilmu Negara (Jakarta: Rajagrafindo Persada, 2016) at 64.

30 W. Bartley Hildreth, Tax Transparency. In Cordes, J. J., Ebel, R. D., Gravelle, G. J., Encyclopedia of Taxation and Tax Policy, 2nd Edition, 2005 (Washington D.C.: The Urban Institute Press, 2005) at 429-430.

31 The handling of the leakage through taxation management transparency is intended to give expediency for the government and taxpayers. See Diane M Ring, "Corporate Migrations and Tax Transparency and Disclosure" (2017) 62:1 St Louis Univ Law J 175 at 185.

32 The background of this statement is from the case of "Panama Paper" from 2016. See Ibid.

33 T M Harrison \& D S Sayogo, "Transparency, participation, and accountability practices in open government: A comparative study" (2014) 31:4 Gov Inf Q 513-525.at 2. 
contribution to pay taxes. ${ }^{34}$ The implementation of tax transparency is an essential factor, and this condition will indicate people fully trusting the government to manage their money. ${ }^{35}$ However, the practice of transparency in the taxation system, the government can close access the information about the tax management system. It potentially to produce a negative impact on the state's financial condition called tax avoidance or evasion. ${ }^{36}$ According to Lai Lan Mo, tax avoidance activities are explained in two terms that is tax avoidance and evasion. It indicates universal symptoms that generally occur in society and the economic system. ${ }^{37}$ The terms of tax avoidance and tax evasions are different terminologies. Although they have different terms, in developing countries, those terms are usually is equal terms. Tax avoidance is an activity to avoid taxes by using legal and regulatory loopholes from various countries, including using the tax haven that is considered legal..$^{38}$ On the other hand, tax evasion is an activity to avoid taxation illegally and violates the rule of law; it indicated by the Act on filing the false information, fabricating tax documents, and making inappropriate tax claims. ${ }^{39}$ According to Nugroho and Agustia cites the statement from Budiman, explained the tax avoidance or evasion was executed by managers in the interests of the company's shareholders. ${ }^{40}$ In this case, the moral issue is that the shareholders will give a reward to the manager to optimizing the work of the company through tax avoidance activities. ${ }^{41}$

Tax avoidance or tax evasion is dangerous activities. ${ }^{42}$ The disadvantages of these activities motivate the state to create a set of regulations. ${ }^{43}$ If a regulation already exists

34 In the data from Performance Reports of Directorate General of Taxations 2018, the tax revenue from the corporation as a legal entity occupied the second-highest value of revenue of 254, 25 Trillion Rupiahs. See Laporan Kinerja Direktorat Jenderal Pajak (LAKIN DJP), by Direktorat Jenderal Pajak Republik Indonesia (Jakarta, 2018).

35 This article states that the right to know the tax management transparently was a form of basics rights for all individuals within a state. See Kenneth S Hall, "The Ethics of Tax Avoidance and Tax Evasion" (2015).at 96.

36 The negative impacts that can happen are the reductions of government income that potentially disrupts the implementations of state fiscal policy. See Robert McGee \& Jovan Shopovski, "The Ethics of Tax Evasion: A Survey of Law and Economics Students in the Republic of Macedonia" (2018) 7:2 Int J Econ Sci 57-69. at 58.

37 See Phyllis Lai Lan Mo, Tax Avoidance and Anti-Avoidance Measures in Major Developing Economies (Connecticut: Greenwood Publishing Group, 2003) at 1.

38 A tax haven is an area that, according to the regulatory provisions, should pay lower taxes than the other areas. See Ibid at 2.

39 It concludes that, actually, those two terms have a different meaning based on the traits between them. See Ibid.

40 W C Nugroho \& D Agustian, "Corporate Governance, Tax Avoidance, and Firm Value" (2017) 2:2 AFEBI Account Rev AAR 16.at 17.

41 The existence of indication about derivations of taxations morale is seen from rewards given for tax avoidance from the managers of the company. See Ibid.

42 That matter is based on its traits that influence the purpose of the state fiscal policy with the decrease of tax revenue. See Shinung Sakti Hantoyo, Kertahadi, Siti Ragil Handayani, "Pengaruh Penghindaran Pajak dan Sanksi Perpajakan Terhadap Kepatuhan Wajib Pajak: Studi pada Wajib Pajak di Kantor Pelayanan Pajak Pratama Tegal", (2016). Jurnal Perpajakan (JEJAK) at 2.

43 As what has been done by the United States using FATCA (The Foreign Account Tax Compliance Act) and CRS (Common Reporting Standard). See Noam Noked, "Tax Evasion and Incomplete Tax Transparency" (2018) 7:3 Laws 31. at 13. 
and its application is impractical, the government must review and provide revisions to the regulation. ${ }^{44}$ This attitude leads to overcoming gaps in tax regulations. However, in the economic sector, tax avoidance is legal because it considered a wise and moral choice to reduce expenditure from the tax sector. ${ }^{45}$ In correspondence with basic terminology, it explains the conditions to implement the tax transparency in Indonesia to reduce the level of tax avoidance. A set of rules in the taxation regulations under these conditions requires the implementation to ensure the stability of the Indonesian taxation system. As the hierarchy of the Act in Article 7 of Act Number 12 of 2011 about The Formation of Laws and Regulations, the discussions would start from the highest legal basis. ${ }^{46}$ The discussions would take from the academic script of regulations, which represents the rationale of lawmaking and the doctrines from scholars.

\section{B. Philosophical Context of Transparency in the Indonesian Tax Law}

Research about philosophical grounds of regulations conducts by finding into the 1945 Constitution. ${ }^{47}$ In the Comprehensive Text of the Amendment to the 1945 Constitution, the discussion of the reasons for changing the constitution seen from the notes of the thoughts of members of the People's Consultative Assembly (Majelis Permusyawaratan Rakyat or MPR). The sections about tax found in the 7th book contains the state's financial affairs. One of the ideas about taxations is outlined in Article 23 paragraph 1 of the 1945 Constitution about financial matters. This section focused on the affirmations of states' purpose to ensure responsibility and openness of the management in state finances. ${ }^{48}$ The affirmation is conducted on the prosperity of the people. This article was created with the purpose of fiscal transparency and ensure the accountability of state financial management. ${ }^{49}$ Sentence "keseluruhan aktivitas keuangan negara"50 define financial matters, such as taxation. This statement indicates the legislator highly consider the state's fiscal transparency. However, in the debate, several figures state that transparency is not a crucial aspect because the people are

44 For the example is the implementation of the automatic exchange of information systems by the government of the United States to boost the effectiveness of FATCA and CRS. See Ibid.

45 Erich Kirchler, Boris Maciejovsky, Friedrich Schneider, "Everyday representations of tax avoidance, tax evasion, and tax flight: Do legal differences matter?" (2001). Humboldt University of Berlin, Interdisciplinary Research Project 373: Quantification and Simulation of Economic Processes.

46 The discussion started by researching the philosophical grounds of 1945 Constitution continued by the lower regulations. See Act Number 12 of 2011 on Legislative Drafting, Article 7 (1).

47 The state's constitution is the highest legal ground that is the 1945 Constitution.

48 This discussion started from the submission of the formulation of change of the constitutions about financial matters from the Expert Team of Economy presented by Dr. Sri Adiningsih. See Tim Penyusun Naskah Komprehensif Proses dan Hasil Perubahan UUD 1945, Naskah Komprehensif Perubahan Undang-Undang Dasar Negara Republik Indonesia Tahun 1945: Buku VII Keuangan, Perekonomian Nasional, dan Kesejahteraan Sosial. (Jakarta: Sekretariat Jenderal dan Kepaniteraan Mahkamah Konstitusi, 2010) at 103.

49 The background of financial transparency and accountability was based on simplifying the Constitution of the United States. Ali Hardi presents this thought. See Ibid at 109.

50 This sentence refers to the presentation from Ali Hardi, which stated that financial management openly and responsible is not only about APBN (Indonesia's States Budget) but also all other regulations with the topics of financial matters. See Ibid. 
poor and uneducated in Indonesia. ${ }^{51}$ This statement can override the common interests of the people and fade the purpose of prosperity for all people without exception.

Although there are particular viewpoints, Indonesians are still relatively poor and uneducated. Eventually, the argument raises the idea that financial transparency and accountability are the patriotic purposes corresponded with the ideology of the state. ${ }^{52}$ Furthermore, the notion of tax arises from the appropriate taxation that supposedly from public awareness. ${ }^{53}$ This idea shows that the execution of taxations is for prosperity and not state coercion. ${ }^{54}$ Also, this statement shows that public awareness is influential, and the decision not to pay taxes is something that naturally happens. This thought is a reflection of the nations that aware of how the tax-managed-the awareness of tax management based on people's ability to think before paying the taxes. ${ }^{55}$ Public awareness about tax payments is demonstrated by tax avoidance or tax evasion. The affirmation of taxpayer rights required to consider because taxpayers must have the same obligations and rights. ${ }^{56}$

In the latest Academic Law Text on General Requirements and Tax Management, the philosophical principle of the 1945 Constitution concerning transparency and financial accountability not clearly stated. This condition based on conflicts in regulations regarding the confidentiality of administrative data. ${ }^{57}$ The problem originated from the philosophical basis of transparency on the background of the Constitution. ${ }^{58}$ The transparency is not contained in the rules strengthened by the regulation of the taxpayer's obligations and not following by the regulation of the taxpayer's rights. ${ }^{59}$ These conditions exposed the 1945 Constitution is not under specific Law about the taxation system. ${ }^{60}$

51 Soedjarto expresses this statement as the representative of Messenger Group Factions (Fraksi Utusan Golongan - F-UG), which states that "sebesar-besarnya kemakmuran rakyat (as possible for the prosperity of the people)" will never be discovered by the poor. See Ibid at 111.

52 Harun Kamil presents this thought as the leader of the conference at that time. At the time, he declared that the thoughts about financial matters that were indicating about transparency and accountability for the prosperity of the people were needed to observe by using the ideological based perspective. See Ibid at 113 .

53 This thought emerges from the statements of Soemitro from Indonesian National Unity Factions (Fraksi Kesatuan Kebangsaan Indonesia - F-KKI), which states that the taxations must base on the people awareness as a form of obligations. See Ibid at 123.

54 Ibid.

55 The awareness from this statement is a form of conscious states of people to understand the nature of the tax that they have paid. There are two grounds of the utilization of tax from the government: first is for the prosperity or only as the act of corruption. See Ibid.

56 Ahmad Zacky Siradj presents this thought from Messenger Group Factions (Fraksi Utusan Golongan - F-UG). He stated a thought about the formulation of rights for taxpayers. It evoked as a response to the reality that the Indonesia Government used too much obligation enforcement to pay the tax at that time. See Ibid at 127.

57 Tim Penyusun Naskah Akademik Rancangan Undang-Undang Tentang Ketentuan Umum dan Tata Cara Perpajakan, Naskah Akademik Rancangan Undang-Undang Tentang Ketentuan Umum dan Tata Cara Perpajakan. (Jakarta: Kementerian Keuangan, 2016) at 13.

58 The phrase "transparency" is firstly used on social aspects of democratic social interactions. See Ibid at 13.

59 It is outlined in a section about the terminology of taxpayers. It clearly stated that emphasize on obligation aspects of the people without any clarifications about the rights that created from it is the 
The implementation of transparency on taxations systems in Indonesia has considerable challenges due to the regulations of state secrecy. In Act of state secrecy, in addition to guaranteeing the people's right to obtain information, the state is also limiting the specific information. ${ }^{61}$ It explained the information about tax management considered as something that could intimidate the economic conditions of the state. ${ }^{62}$ The statement contradicts the underlying fiscal policy as a method to implement transparency and accountability. ${ }^{63}$ This explanation also indicates the different purposes among the constitution-makers who want openness information to implement a fiscal policy for the public. ${ }^{64}$

\section{THE APPLICATION OF TAX LAWS IN RESPONSE TO THE TAX AVOIDANCE}

Implementing the law is an attempt to increase the openness of tax management information for the people ${ }^{65}$ by creating a set of rules or an Act. The purpose of implementing this regulation is to create a legal basis for excellent procedures in tax management. ${ }^{66}$ One of the basic functions of the law is guaranteed the right to freedom

obligation. This situation is giving an unbalanced part between the rights and obligations which continue to generate the provisions about the tights of taxpayers not formulated on the act of general requirement and taxations management. This situation reflects the lacuna of legal certainty for the taxpayers related to the transparency of tax management that they have paid to the states. See Ibid at 35.

60 This situation reflected from no relations between the implementations of the concept of transparency that was the element of open states financial management constitutionally with the Act Number 6 of 1983 about General Requirement and Taxations Management. See the Indonesian 1945 Constitution and Taxation Procedure Act No. 6 of 1983.

61 Tim Penyusun Naskah Akademik Rancangan Undang-Undang Tentang Rahasia Negara, Naskah Akademik Rancangan Undang-Undang Rahasia Negara. (Jakarta: Kementerian Pertahanan, 2016) at 45.

62 The provision was written on the sections of Section (d) Article 17 of Act Number 14 of 2008 about The Open Access of Public Information. See Ibid at 56.

63 This contradiction was based on that the theory about the state's economic threats, which, if linked into the doctrinal studies of academic research about transparency on the tax system, is contradictory. This situation can be seen through the research results that instead recommended the open-access of information on tax management from the government of the state. See Harrison $\&$ Sayogo, supra note 33. dan Jonathan Barrett, "Democratic discourse, taxation and hypothecation" (2012) 14:1 J Aust Tax 89. pp. 109.

64 Tim Penyusun Naskah Komprehensif Proses dan Hasil Perubahan UUD 1945, supra note 45. at. 113.

65 The change of legislation and a constitutional amendment is used for an alternative to giving the authority for the government to widen the relations with the public. This step executed simply for the sake of hearing the voice of the public and realizing the transparency to bolster up the effectiveness of the democratic fiscal policy. See Lobna M Abdellatif et al, "Transparency of law making and fiscal democracy in the Middle East" (2019) 43:1 Public Sect Econ 49-77.at 51.

66 The existence of several prior research stated that the god factors of tax management also influenced by the role of the institutions. This kind of factor is the performance of tax revenue. Several factors were affecting these conditions, which one of them was the rule of law to resolve the corruption in taxation sectors to balance the rights and obligations of the people insides the taxation system. See Tahseen Ajaz \& Eatzaz Ahmad, "The Effect of Corruption and Governance on Tax Revenues" (2012) 49:4 Pak Dev Rev 405-417.at 410. 
of society ${ }^{67}$ to know the process of tax management by the state through taxation. ${ }^{68}$ The establishment of excellent management is required in the laws that strengthened by the characteristic of the law. This characteristic to harmonize the condition of society through the concept of rules to guarantee the rights in society. ${ }^{69}$ It based on a democratic system of the government through the tribute of the people's choices. ${ }^{70}$ Further review is needed to ensure the rights of society to obtain information openness. ${ }^{71}$ This argument is directed to explain the state authority in holding or providing information to the public without damaging transparency as the people's rights. The implementation of this action can be achieved by using the method of taxation democracy.

Following the philosophical reasons, the formulator of the 1945 Constitution, taxation based on the awareness of people. ${ }^{72}$ In addition to using repressive methods from the government, taxation must emphasize taxpayer rights. ${ }^{73}$ It is consistent with the government form of Indonesia to accentuate the people trust. ${ }^{74}$ Transparency in $^{2}$ taxation as a program can maintain the legitimacy of authority according to the sovereignty of people, and the information becomes a fundamental factor. ${ }^{75}$ Public opinions of the taxation system with the transparency would develop the state to become an excellent state and ensure the trust of the people towards the government. ${ }^{76}$ This public trust is formed from tax management information by actualizing information openness; it simplifies the function of people to oversee decisions of the

67 In addition to the authority, the law should keep developing for revolving its paradigm not as a media to enforce with fears but because the people have their role in increasing the effectiveness of the government. See Good governance: the rule of law, transparency, and accountability, by Michael Johnston (New York, 2006). at 2.

68 Those rights based on the traits of the citizens as specialized taxpayers and are a form of duty that should be executed. The existence of the traits caused the management of tax to have a duty to open its information to the public so the people can understand their tax payment and the benefits that have been provided by the government from those taxes. See Barrett, supra note 62.

69 Raymond Wacks, Philosophy of Law: A Very Short Introduction (Oxford: Oxford University Press, 2006).at 52.

70 The legality of the democratic government stands on the hands of people, and any elements of the government need to do their duty as representative people's hope. See T R Tyler, "Trust and democratic governance" in V V A Braithwaite \& M Levy, eds, Trust Gov (New York: Russell Sage Foundation, 1998) l.at 269.

71 No restrictions of information should do the emphasis on transparency. The open-access of information would actualize active cooperation between government and taxpayers suitable with the planning aspect and precise regulations based on transparency. See Hall, supra note 35. at 3.

72 Tim Penyusun Naskah Komprehensif Proses dan Hasil Perubahan UUD 1945, supra note 45 at 123.

73 Taxations legally need to form by using not only with repressive methods but also a strategy so the law can be seen in renewal perspectives. See Johnston, supra note 66.

74 Tyler, supra note 69.at 269.

75 This term was based on the thought that democratic governance needs proper information management to optimize its functions. See Teresa M. Harrison \& Djoko Sigit Sayogo, supra note 33 at 1 .

76 This statement was signified by accountability that has a role in reinforcing sustainable trust and synergy between the government and the public. See Ibid dan Whitney B Afonso, "Fiscal Illusion in State and Local Finances: A Hindrance to Transparency" (2014) 46:3 State Local Gov Rev 225. 
government taxation system. ${ }^{77}$ This indicator explains the limited information created for the benefit of the government, which has the potential to decrease the essence of Indonesia. This situation arises because of the diversion from the original purpose in the formation of Indonesia that led to the prosperity of the people.

Public awareness of dishonesty and not transparency of government in the taxation system results in tax avoidance activities. This situation follows the previous statement in the 1945 Constitution outlines tax avoidance as it already happened. ${ }^{78}$ This trait is inappropriate to be eradicated using repressive law. This condition is motivated by the limitation of democratic awareness of the people and the fertilization of authority domination. This tax avoidance is a public awareness that arises from the view of the obligation to obey. ${ }^{79}$ It happens if a corruption act indicates the government deviates from its path. This indication lead tax avoidance is becoming an obligation that must be fulfilled. ${ }^{80}$ This statement is based on the logic that corruption is dangerous for taxpayers. ${ }^{81}$ The statement 'a country cannot develop without taxes' is irrelevant because the state can apply direct and indirect taxation, such as public services, and voluntary public contributions. ${ }^{82}$ If these sectors cannot generate funds through the application of transparency, the government has the authority to cut these sectors so; it provides people an excuse to pay appropriate taxes.

\section{CONCLUSION}

Essential aspects of transparency and accountability occur on the characteristics to ensure public trust towards the government. ${ }^{83}$ Public trust can make tax management operate effectively based on the principles of good governance. ${ }^{84}$ However, the limitation of legal information from tax management has the potential to create an

77 The surveillance was carried out, so the accountability that has been implemented by the government could operate as it should and open the role of the people to enable them to analyze the deficiency inside its implementations within the taxations system. See Ibid at 2.

78 The indicators of normality showed by awareness of people whom the government always suppressed it with obligations without any rights as the taxpayers. These conditions naturally would invent the doubt from the people towards the government, which not giving any reports about the utilizations of the tax payment from every taxpayer. See Tim Penyusun Naskah Komprehensif Proses dan Hasil Perubahan UUD 1945, supra note 48 at 123.

79 Robert W. McGee, The Ethics of Tax Evasion: Perspectives in Theory and Practice. (New York: Springer Science+Business Media, 2012) at 17 .

80 Ibid, pp. 18.

81 Emphasize the perspective of the people as a work evaluator of the government of state is a form of democracy and naturally should have been done by the democratic state. See Ibid.

82 Ibid at 52.

83 A democratic country should ensure the trust of its people to ensure the performance of its governance. See James R Hollyer, B Peter Rosendorff \& James Raymond Vreeland, "Democracy and Transparency" (2011) 73:4 J Polit 1191-1192.

84 Indonesia, as a developing country, is included as the indicator as countries that still have a challenge to developing the criteria of good governance. Therefore it is necessary to make efforts to develop the criteria of good governance. See Dom \& Miller, supra note 22. 
effect of public mistrust. ${ }^{85}$ It raises a phenomenon of tax avoidance that requires strict law enforcement. ${ }^{86}$ The background of this condition is that tax avoidance activities reflect the patriotic culture. The existence of tax avoidance activities is a representative the public awareness to participate in the government system. ${ }^{87}$ This idea is the basis for supporting the application of a good governance system of tax management.

There has been a challenge regarding implementation of specific regulations about the taxation issues in Indonesia, from the imbalance existence of transparency and state secrecy. ${ }^{88}$ Transparency obstructed by factors of state secrecy creates public opinion that will lead to tax avoidance or evasion. This situation shows that the public is aware and understands. Repressive restrictions from the state through the regulations have the potential to occur the conflicts between the public and the government; it will fade the essence of the state formed for the common good of the people. ${ }^{89}$ However, this conclusion does not eliminate the role of law to reduce the intensity of tax avoidance activities. This practice is based on the characteristics of the law as a service to ensure public rights and realize justice. Legal efforts are making regulations focus on the viewpoint of reform. ${ }^{90}$

The legal traits focused on the renewal perspectives manifested by the democratic system with the tax policy procedures. Tax policies, execute democratically with the transparency efforts in the tax management system. The transparency actualizes the relations between components of the state based on trust. ${ }^{91}$ Trust arises from openness to access information to supports government performance. Support can increase the effectiveness of the government to executes its duties as public oversight of state tax management. The continuity of the practice of tax transparency and accountability from the rule of law focuses on the perspective of renewal creates active collaboration between the components of the country. Active collaboration and focus on prosperity creates transparency from a renewal perspective that will determine the essence of the country. ${ }^{92}$ It concluded that the implementation of taxations transparency in regulations would potentially preserve the implementation of the public relation to actualize the purpose of states as the practice of the nature the state. Indonesia, as a

85 This conclusion declared that the restrictions of information need precise criteria inside the regulations. Given that the law is still not giving any accurate explanations about certain restrictions of information to the public. See Alejandro Esteller-More' \& Jose' Polo Otero, "Fiscal Transparency" (2012) 14:8 Public Manag Rev 1153.

86 See Johnston, supra note 67.

87 Tim Penyusun Naskah Komprehensif Proses dan Hasil Perubahan UUD 1945, supra note 48 at 123.

88 The overlaps that stationed were evoking the dilemma between ensuring the open-access of information for a public purpose or the purpose of the government. See Tim Penyusun Naskah Akademik Rancangan Undang-Undang Tentang Ketentuan Umum dan Tata Cara Perpajakan, supra note 54.

89 The existence of exaggerated legal repressive actions can trigger the reluctance of people to cooperate with the state. See Johnston, supra note 67.

90 Emphasize this term is for a renewal perspective from the repressive perspective of law. See Ibid.

91 Harrison \& Sayogo, supra note 33.

92 The continuity that happens would lead to the traits of the state that are from a group of people that would lead the people into prosperity. See Alesina \& Bryony, supra note 3. 
state with a democratic system, expected to implement the concept of transparency to maintain the essence of the state.

\section{ACKNOWLEDGMENTS}

None.

\section{COMPETING INTERESTS}

The authors declare that they have no competing interests.

\section{REFERENCES}

Besley, Timothy \& Torsten Persson. "Taxation and Development" in Raj Chetty, ed, Handb Public Econ Vol 5, lst ed (North Holland, 2013) 51.

Dom, Roel \& Mark Miller. Reforming tax systems in the developing world: What can we learn from the past? (London, 2018).

Hildreth, WB. "Tax Transparency" in J J Cordes, R D Ebel \& G J Gravelle, eds, Encycl Tax Tax Policy, 2d ed (Washington D.C.: The Urban Institute Press, 2005).

Indonesia, Direktorat Jenderal Pajak Republik. Laporan Kinerja Direktorat Jenderal Pajak (LAKIN DJP) (Jakarta, 2018).

Johnston, Michael. Good governance: Rule of law, transparency, and accountability (New York, 2006).

Lai Lan Mo, Phyllis. Tax Avoidance and Anti-Avoidance Measures in Major Developing Economies (Connecticut: Greenwood Publishing Group, 2003).

McGee, R W. The Ethics of Tax Evasion: Perspectives in Theory and Practice (New York: Springer Science+Business Media, 2012).

Satriawan, M Iwan \& Siti Khoiriah. Ilmu Negara (Jakarta: Rajagrafindo Persada, 2016).

Soehino. Ilmu Negara (Yogyakarta: Liberty Yogyakarta, 2015).

Susanti, Dyah Ochtorina \& A'an Efendi. Penelitian Hukum (Legal Research) (Jakarta: Sinar Grafika, 2018).

Tim Penyusun Naskah Akademik Rancangan Undang-Undang Tentang Ketentuan Umum dan Tata Cara Perpajakan. Naskah Akademik Rancangan Undang-Undang Tentang Ketentuan Umum dan Tata Cara Perpajakan (Jakarta: Kementerian Keuangan, 2016).

Tim Penyusun Naskah Akademik Rancangan Undang-Undang Tentang Rahasia Negara. Naskah Akademik Rancangan Undang-Undang Rahasia Negara (Jakarta: Kementerian Pertahanan, 2016).

Tim Penyusun Naskah Komprehensif Proses dan Hasil Perubahan UUD 1945, Naskah Komprehensif Perubahan Undang-Undang Dasar Negara Republik Indonesia Tahun 1945 : 
Buku VII Keuangan, Perekonomian Nasional, dan Kesejahteraan Sosial (Jakarta: Sekretariat Jenderal dan Kepaniteraan Mahkamah Konstitusi, 2010).

Tyler, T R. "Trust and democratic governance" in V V A Braithwaite \& M Levy, eds, Trust Gov (New York: Russell Sage Foundation, 1998) 1.

Utrecht, E \& Moh Saleh Djindang. Pengantar Dalam Hukum Indonesia (Jakarta: Ichtiar Baru, IKAPI, Sinar Harapan, 1995).

Wacks, Raymond. Philosophy of Law: A Very Short Introduction (Oxford: Oxford University Press, 2006).

Abdellatif, Lobna $\mathrm{M}$ et al. "Transparency of law making and fiscal democracy in the Middle East" (2019) 43:1 Public Sect Econ 49.

Afonso, Whitney B. "Fiscal Illusion in State and Local Finances: A Hindrance to Transparency" (2014) 46:3 State Local Gov Rev 225.

Ajaz, Tahseen \& Eatzaz Ahmad. "The Effect of Corruption and Governance on Tax Revenues" (2012) 49:4 Pak Dev Rev 405.

Alesina, Alberto \& Reich Bryony. "Nation building" (2013) wl8839 Natl Bur Econ Res.

Barrett, Jonathan. "Democratic discourse, taxation and hypothecation" (2012) 14:1 J Aust Tax 89.

Esteller-More', Alejandro \& Jose' Polo Otero. "Fiscal Transparency" (2012) 14:8 Public Manag Rev 1153.

Fasmi, Lasnofa \& Fauzan Misra. "Modernisasi Sistem Administrasi Perpajakan dan Tingkat Kepatuhan Pengusaha Kena Pajak” (2014) 5:1 J Akunt Multiparadigma JAMAL 1 .

Hantoyo, SS, Kertahadi \& S R Handayani. "Pengaruh Penghindaran Pajak dan Sanksi Perpajakan Terhadap Kepatuhan Wajib Pajak: Studi pada Wajib Pajak di Kantor Pelayanan Pajak Pratama Tegal" (2016) 9:1 J Perpajak.

Harrison, T M \& D S Sayogo. "Transparency, participation, and accountability practices in open government: A comparative study" (2014) 31:4 Gov Inf Q 513.

Hollyer, James R, B Peter Rosendorff \& James Raymond Vreeland. "Democracy and Transparency" (2011) 73:4 J Polit 1191.

Horodnic, Ioana Alexandra. "Tax morale and institutional theory: a systematic review" (2018) 38:9/10 Int J Sociol Soc Policy 868.

Hutchinson, Terry. "Doctrinal research: researching the jury" in Dawn Watkins \& Mandy Burton, eds, Res Methods Law (Oxford: Routledge, 2013) 8.

Jamei, Reza. "Tax Avoidance and Corporate Governance Mechanisms: Evidence from Tehran Stock Exchange" (2017) 7:4 Int J Econ Financ Issues 638.

Johnson, Noel D. "Taxes, National Identity, and Nation Building: Evidence from France" (2015) Georg Mason Univ Dep Econ Pap 1.

Kirchler, E, B Maciejovsky \& F Schneider. Everyday representations of tax avoidance, tax evasion, and tax flight: Do legal differences matter?, Interdisciplinary Research Project 373: Quantification and Simulation of Economic Processes 43 (Berlin, 2001).

Laroche, Mireille, Marcel Merette \& GC Ruggeri. "On the Concept and Dimensions of Human Capital in a Knowledge-Based Economy Context" (1999) XXV:1 Can 
Public Policy 90.

McGee, Robert \& Jovan Shopovski. "The Ethics of Tax Evasion: A Survey of Law and Economics Students in the Republic of Macedonia" (2018) 7:2 Int J Econ Sci 57.

Mutaqin, Zezen Zaenal. "The Strong State And Pancasila: Reflecting Human Rights in the Indonesian Democracy" (2016) 2:2 Const Rev 160.

Noked, Noam. "Tax Evasion and Incomplete Tax Transparency" (2018) 7:3 Laws 31.

Nugroho, W C \& D Agustian. "Corporate Governance, Tax Avoidance, and Firm Value" (2017) 2:2 AFEBI Account Rev.

Oats, Lynne \& Penelope Tuck. "Corporate tax avoidance: is tax transparency the solution?” (2019) 49:5 Account Bus Res 565.

Ring, Diane M. "Corporate Migrations and Tax Transparency and Disclosure" (2017) 62:1 St Louis Univ Law J 175.

Ríos, Ana-María, Francisco Bastida \& Bernardino Benito. "Budget Transparency and Legislative Budgetary Oversight: An International Approach” (2016) 46:5 Am Rev Public Adm 547.

Thaçi, Lumnije \& Arbnora Gërxhaliu. "Tax Structure and Developing Countries" (2018) 4:1 Eur J Econ Bus Stud 213.

Torgler, Benno. "Tax morale and direct democracy" (2005) 21:2 Eur J Polit Econ 526.

Wasylenko, Michael et al. "Taxation and economic development: The state of the economic literature” (1997) 2:1 New Engl Econ Rev 37.

Wehner, Joachim \& Paolo De Renzio. "Citizens, Legislators, and Executive Disclosure: The Political Determinants of Fiscal Transparency" (2013) 41:3 World Dev 96.

McLure, C E, M S Cox \& F Neumark. Taxation (2018). 
100 | Transparency Regarding the Tax Avoidance in Indonesia: A Philosophical Review

This page is intentionally left blank 